\title{
Impact of Corporate Restructuring on Value Creation in the Nigerian Banking Industry \\ Sebastine Seddi Maimako
}

University of Jos, Jos, Nigeria

Kolawole Olugbenga Oladele

Nigerian Defence Academy, Kaduna, Nigeria

\begin{abstract}
This study aims at determining the impact of corporate restructuring on the creation of shareholder value in the Nigerian banking industry. Secondary data are collected in respect of all the 21 banks listed on the Nigerian Stock Exchange. The data are analysed using the Difference in Means (Descriptive Statistics) Method. The study establishes the fact that in the Nigerian banking industry, mergers, acquisitions and capital restructuring have significant impacts on value creation; but capital restructuring has the greatest positive impact on the creation of shareholder value. It is also found that most banks have to restructure as a result of problems like weaknesses in corporate governance, weak ownership structure, conflict of interest between management and shareholders, environmental problems, and internal problems. The findings of this study imply that banks involved in mergers may not be able to create or enhance value for their shareholders. It is recommended that industry regulators and practitioners seeking to create value for shareholders should, among other things, focus on capital restructuring and acquisition and strategies that favour growth, expansion and performance improvement.
\end{abstract}

Keywords: Corporate Restructuring, Banking, Mergers, Acquisitions, Shareholder Value, Value Creation, Performance Improvement

\section{Introduction}

Recent decades have seen a plethora of new management approaches for improving organizational performance which include "Balanced Scorecard", "Total Quality Management (TQM), best practice "Benchmarking", "Flat Organizations", "Empowerment" or Business Process Re-engineering (BPR). Many performance managers borrow from or utilize these approaches because they want to achieve their strategic objectives and/or promote their organizations' missions and values (Salem, 2003). Koller (1994) believes that although some reasonable success has been achieved by using these approaches, some of them have failed either because their performance targets were not very clearly set or they were not set with the objective of creating value for their stakeholders. Echebarria-Miguel and Barrutia-Legarreta (1999) support this opinion and argue that since today's business world is becoming more and more complex, incomplete ideas or actions intended to deal with business realities can no longer be effective. Hence, the emergence of a new management paradigm: Value Creation - a renewed approach to business management which pursues the creation of shareholder value through the delivery of value to customers and business associates. In the same vein, Rossi (2006) also confirms that all strategic performance variables like short-term nancial results, customer relations, employee relations, operational performance, quality alliances, supplier relations; 
environmental performance and innovation are significantly related to market value/book value (M/ B) ratio, shareholders' annual returns and shareholders' abnormal returns.

The arguments about the creation of shareholder value through the improvement of corporate performance offer sufficient support for the role of corporate governance in the creation of shareholder value. The Central Bank of Nigeria (CBN) (2006) defines corporate governance as "a system by which corporations are governed and controlled with a view to increasing shareholder value and meeting the expectations of other stakeholders". In the opinion of Maimako (2010:3) "corporate governance is the way and manner in which a company is managed in the best interest of shareholders and other stakeholders". It follows, therefore, that in order to create value for its shareholders, the control and management of an organization must be based on the principles of accountability, transparency and probity, and focus on long-term success of a company.

The Nigerian banking industry has witnessed periodic bank distresses and failures due to inadequacy of capital and other operational problems. Brownbridge (1998) observes that although the banks were set up to provide benefits to the domestic economy and facilitate the objectives of financial liberalization, the objectives could not be achieved because the local banks became susceptible to financial distress. Muhammed (2005) also opines that most Nigerian banks were becoming tailored in concentration, ownership and management structure. As a result, they were not able to profitably set in motion the growth levers and balance tactical and strategic growth initiatives for successful growth and control the competencies crucial in developing a focused approach to compete in foreign markets.

Besides, many of the smaller banks in Nigeria were owned almost exclusively by one person or members of the same family. In times of merger propositions, many of the owners were not willing to let go. According to Osho (2004: 59), "they prefer to be 'emperors' in their small 'enclaves' rather than being bit players in a 'big empire'". Also, an examination conducted by the CBN and Nigerian Deposit Insurance Corporation (NDIC) in 2009 showed that some of the banks lacked adequate capital required to provide against possible loan losses or other problems; funds for their internal needs and for expansion; and added security for depositors and the deposit insurance system. This is a very clear indication that depositors' funds were being used to fund the growth in fixed assets (Umoh, 2004).

Other problems, which characterized the Nigerian banking industry, included regulatory intervention, market/economic considerations, mismanagement, skill gaps, and political interference. The overall implication of all these problems is that, with or without the corporate restructuring efforts, Nigerian banks were performing below the expectation of stakeholders (shareholders, customers, employees, etc.) because they failed to drive profitability beyond the cost of equity. In other words, they declared unrealistic (false) profits while they actually made losses. This showed that the Nigerian banks were not generating any significant returns for their shareholders. There was, therefore, a consensus that the prevailing unhealthy state of the banking industry required a drastic overhaul as a precursor for a full scale reform of the economy.

The motivation for this study is that despite the volume of existing literature on value creation, corporate restructuring and the banking industry, gaps still exist. Several studies have been conducted which focus on the determinants of profitability and performance of the banking industry in Greece (Varelas, Karpetis and Konokarpeti, 2004; and Athanasoglou, Brissimis and Delis 2005), Tunisia (BenNaceur and Goaied, 2001 and Naceur, 2003) and Colombia (Barajas, Steiner and Salazar, 1999), and Malaysia (Katib, 2000). None of these studies, 
however, examines the concept or issue of creation shareholder value. On the other hand, several studies like Naccur (2003) and Boston Consulting Group (2003, 2005, 2007 and 2008), which dwell on the creation of shareholder value, did not link the concept to corporate restructuring. In addition, they did not take Nigeria into consideration.

Similar studies, which link corporate restructuring to the creation of shareholder value, also did not take Nigeria into consideration. For instance, Gilson (1998) and Gleason, Mathur and Wiggins III (2003) focus on United States of America; Hailemariam (2001) focuses on Eritrea; Boston Consulting Group (BCG) $(2003,2005$, 2007, and 2008) concentrate on Europe, America and Asia; Sanyal and Shankar (2005) focus on India; Shivdasani and Kang (1996) focus on Japan while Mahmood and Mohamad (2007) based their own study on Malaysia.

Furthermore, despite the volume of comments and expression of opinions about the Nigerian consolidation exercise by Nigerians and international observers, no study or research was found conducted to specifically investigate how the restructuring activities undertaken by the banks will impact the creation of shareholder value in the Nigerian banking industry. This study, therefore, aims at examining the impact of corporate restructuring on the creation of shareholder value in the Nigerian banking industry between 2000 and 2009.

The remainder of the paper is organized follows: Section 2 focuses on Prior Research; section 3 discusses the Methodological Issues; Section 4 is on the Data used for the study; Section 5 concentrates on the Research Findings; while Section 6 provides Conclusions and Recommendations.

\section{Prior research}

\section{The Meaning of Value}

Various concepts of value have been proposed in the accounting literature. Qureshi and Briggs (2003) argue that although value is often measured in monetary terms, it can manifest in many dimensions. Value may be cognitive (Young, 2001); social (Seligman, 1905, Qureshi and Briggs, 2003); political (Qureshi and Briggs, 2003, Faccio, Masulis and McConell, 2005); emotional (Barlow and Maul, 2000). In addition to the above, Smith, (1776) also identifies use value and exchange value.

From the foregoing, value can simply be defined the worth of something estimated by any standard of purchasing power, especially by the market price. Thus, when a firm creates value for its stakeholders, it improves or increases their worth by their own estimation. In this study, however, the focus is on the creation of value for shareholders. That is increase in the financial worth of shareholders as measured by ratio of market value of shares to the book value of shares.

\section{The concept of value creation}

Value creation is improvement in the shareholders' wealth brought about by the activities of an organization. Pandey (2002:1181) agreeing with Fruhan (1979) defines the created value as "the excess of market value over book value per share". In the opinion of Hailemariam (2001) and Valez-Pareja (2001), a firm creates value for its shareholders when the firm's return on assets is greater than its cost of capital. Fernandez (2002:11) supports this line of thought. It is usually indicated by increase in the firm's market value of shares (although other macroeconomic variables, like inflation, can also cause an increase in the market value of shares).

In addition, BCG reports (2005, 2006, 2007, and 2008) and analyses of Asia, Eastern Europe and Central Europe have shown that profitability improvement, performance improvement; organic growth, successful acquisitions decisions, capital allocation improvement, sophisticated customer relationship management (CRM) approaches are the main reasons for strong performance in the global banking industry. 


\section{The value creation model}

Several financial models for the determination of shareholder value creation have been developed. Of all these models, only the market value-to-book value per share (MV/BV) model is used in the study and is discussed in details below.

\section{Market Value-To-Book Value per Share (MV) BV) Model}

This model relates the market value to the book value per share and determines the ratio. In this approach, Pandey (2002) explains that a firm creates value for its shareholders when the ratio of the market value per share (MV) to the book value per share (BV) becomes greater than 1. By definition, the market value of a firm's share is the present value of the streams of dividend per share (DPS) expected in the future. The streams of dividend per share is in turn determined by the firm's dividend payout ratio, $(1-b)$ and the rate at which the firm's earnings grow, g. In its own case, earnings growth rate depends on the retention ratio, $b$ and the return on equity, ROE. Therefore, if we assume that the time horizon, $\mathrm{n}$ is finite, then the ratio of the market value per share to the book value per share, MV/BV becomes:

$$
\frac{\mathrm{MV}}{\mathrm{BV}}=\left[\frac{\mathrm{ROE}-\mathrm{g}}{\mathrm{k}_{\mathrm{e}}-\mathrm{g}}\right]\left[1-\left(\frac{1+\mathrm{g}}{1+\mathrm{k}_{\mathrm{e}}}\right)^{\mathrm{n}}\right]+\left[\frac{1+\mathrm{g}}{1+\mathrm{k}_{\mathrm{e}}}\right]^{\mathrm{n}}
$$

Where:

$\begin{array}{lll}\mathrm{MV} & = & \text { Market value per share } \\ \mathrm{BV} & = & \text { Book value per share } \\ \mathrm{ROE} & = & \text { Return on equity } \\ \mathrm{k}_{\mathrm{e}} & = & \text { Cost of equity } \\ \mathrm{g} & = & \text { Earnings growth rate } \\ \mathbf{n} & = & \text { Time horizon }\end{array}$

The above equation presented by Pandey (2002) is consistent with the definition of Fruhan (1979). From the above equation, the drivers of value include economic profitability or spread, growth, and investment period.
The market value/book value model is the model that has been selected for the purpose of the empirical analysis in this study because the information required for the use of the method is readily available as secondary data. Besides, the model has been widely used in literature. For instance, the model was used by Pandey (2002) to test the data relating to Indian companies. It was also used by Van Horne (2002) to test the data relating to American Companies. Naceur (2003) and Naceur and Goaied (2003) also used the model to test the data relating to Tunisian companies. In this study, this model is used in its original form to test the data relating to the Nigerian banking industry.

Penrose (1959), Rappaport (1987), Caby and others (1996), Slater and Zwirlein (1996: 253-66), Moran and Ghoshal (1997: 55), Ghoshal, Hahn and Moran (1997: 57), Hellwig (1998: 141-47), Bartram (2000: 279-342), Bounfour (2000: 111-24), Pierrat and Martory (2000), Pariente (2000), de-Andres-Alonso, AzozfraPalenzuel and Rodriguez-Sanz (2000), Ramezani, Soenenand Jung (2001), Fuller and Jensen (2002), BCG, (2005), García-Herrero (2003), Aghion and Stein (2006), Chander and Aggarwal (2007), Fairfield, Ramnath and Yohn (2005), Glushkov (2007), Levesque and Minniti (2007), Lockett, Wiklund and Davidsson (2007), Gong, Louis and Sun (2007), Martin (2007), Fama and French (2007) and Sadka and Sadka (2008) have identified several drivers of value creation to include growth rate, operating profit margin, income tax rate, working capital, fixed capital investment, cost of capital and value growth duration. However, in order to determine, empirically, the main determinants of value creation, Ben-Naceur and Goaied (2001) and Naceur and Goaied (2003) have combined the measures of value creation with the value drivers and identified three determinants of value creation as profitability, dividend policy and financial policy. 


\section{Value Creation and Corporate Restructuring}

Apart from the factors identified earlier, academicians, scholars and business practitioners have also established a strong correlation between the created shareholder value and corporate restructuring. Corporate Restructuring is a broad umbrella that covers many things. One thing is merger another is acquisition or takeover. From the buyer's stand point, this represents expansion. But from the seller's stand point, it represents a change of ownership, which may or may not be voluntary. According to Van Horne (2002:719), "The name 'Corporate Restructuring' can be construed as almost any change in capital structure, in operations, or in ownership that is outside the ordinary course of business." On the other hand, the restructuring of a firm in financial distress is different because in this case, the pressure to restructure is from outsiders creditors. When this is the case, there exist certain defined remedies which must be observed in case of restructuring. Whatever the case is, however, management is still in position to influence the outcome of any restructuring.

According to Gilson (1998:1), "restructurings are meant to address corporate underperformance, financial distress, changes in business corporate and strategic policy, and information gaps between the firm and the capital markets". For most firms however, restructuring is a response to severe financial stress, following large declines in firm's shareholder returns, market value, or competitive position.

Corporate restructuring is characterized and evidenced by three main elements: operating activities, financing activities and investing activities. Filatotchev, Buck and Wright (1996) argue that changes in the operations, financing and governance are essential elements of restructuring. Bowman, Singh and Bhadury (1999) identify three major categories of restructuring activities. Portfolio restructuring, which includes significant changes in the mix of assets owned by a firm or the lines of business in which a firm operates, including liquidation, divestitures, assets sales, and spin-offs; Financial restructuring, which includes significant changes in the capital structure of a firm including leveraged buyouts, leveraged recapitalizations, and debt for equity swaps; and organizational restructuring, which includes significant changes in the organizational structure of a firm including redrawing of divisional boundaries, flattening of hierarchic levels, spreading of the spans of control, reducing product diversification, revising compensations, streamlining processes, reforming governance and downsizing employment.

There is a general agreement among authors that the restructuring of an organization impacts on the performance of that organization in different ways depending however, on the organization, the type of restructuring undergone, and the immediate and long-term environment of the organization. While some forms of restructuring assist in the creation of value for the share holders, others do not. In fact, in some cases, value is destroyed.

The various techniques of corporate restructuring are widely discussed in literature by several authors and scholars (Kazmi, 1992; Brealey and Myers, 1996; Olowe, 1997; Brealey, Myers and Marcus, 1999; McCarthy, Minichiello and Curran, 2000; Pearce and Robinson, 2000; Van Horne, 2002; and Pandey, 2002 among others). These techniques have been broadly described as 'Reconstruction Schemes' by BPP (2009) which also discusses them under three categories financial restructuring, portfolio restructuring and organizational restructuring. This classification agrees with the earlier classification of Bowman et al. (1999). This study however, is focused on three main restructuring activities, which are mergers, acquisitions and capital restructuring.

Of all restructuring activities, business combinations in the form of mergers and acquisitions appear to be 
more prominent in literature. Brealey and Myers (1996), Pandey (2002) and Van Horne (2002) discuss different types of business combinations. A merger, on the one hand, is the combination of two or more corporations in which only one survives. Amalgamation is the merger of one or more firms with another firm or the merger of two or more firms (amalgamating firms) to form a new firm (amalgamated firm). A merger or an amalgamation may take the form of absorption or consolidation. Absorption is the combination of two or more firms into an existing firm in which case, all firms, except the absorbing firm lose their identities. In the case of consolidation, two or more firms combine to form an entirely new firm in which case, all combining firms, except the new firm lose their identities.

Acquisition, on the other hand, is fundamental characteristic of a merger either by absorption or consolidation in which case, the acquiring firm takes over the ownership of other firms and combines their operations with its own operations. Thus in an acquisition, two or more firms may remain independent, separate legal entities but with changes in the control and management of the firms (Pandey, 2002). The acquisition takes place either by the purchase of assets or shares of the 'dead' company by the surviving company. The payment for the acquisition can be made either by cash or by the issue of shares. If the transaction is made with cash or with a debt instrument, it is taxable to the selling company or to its shareholders. But if the payment is made with the issue of shares, the transaction is not taxable at the time of the sale.

Acquisitions or mergers offers three types of synergy as gains: these are revenue, cost and financial synergies. The existence of synergies offers two major explanations as to why it is possible for acquisition to increase the value created for the shareholders of the firms involved. Because the shareholders of the firms involved require the persuasion of the management to support the merger, it is very essential, therefore, to identify, quantify and announce these synergies as essential parts of the merger process (BPP, 2009).

In order to finance a merger or an acquisition, payment can be in the form of cash, a share exchange or convertible loan stock. The choice will depend on available cash, desired levels of gearing, shareholders' taxation position and changes in control. The terms of a takeover will involve a purchase of the shares of the target company for cash or for 'paper' (shares, or possibly loan stock). A purchase of a target company's shares with shares of the predator company is referred to as a share exchange.

When companies merge and are taken over, the aim is to create value. Van Horne (2002) advances several reasons why one may expect value to be created or rearranged in a merger situation. These reasons are sales enhancement and operating economies; improved management; information effect; tax effects; diversification; transfer of wealth; hubris hypothesis (Van-Horne, 2002:697); and management's personal agenda (Goddard, Molyneux, and Wilson 2004:1069-90; BCG, 2005:5; Mahmood and Mohamad, 2007).

A number of alternative theories explain the phenomenon of failure by postulating that the main motive of the management of a company when they bid for another company is not maximization of the shareholder value, but other motives which have been found to be consistent with empirical evidence. Some of these motives are evidenced by: Agency theory; Errors in valuing a target firm; Market irrationality; Pre-emptive theory; and Window dressing. Based on the foregoing, therefore, it can be concluded that while many reasons exist for mergers and/or acquisitions, only some actually result in value creation. 


\section{Rationale for Banking Sector Restructuring in Nigeria}

A sound banking industry must, among other things, be able to facilitate economic development, provide a platform for sound monetary policy implementation as well as ensure price stability. However, the structure of the Nigerian banking industry, pre-consolidation, inhibited its effective performance as it was characterized by a number of structural and operational inadequacies.

The desire to remedy these inadequacies provided the raison d'être and the impetus for the current reforms. The inadequacies included low capital base, large number of small banks with relatively few branches, poor rating of some of the banks, weak corporate governance including inaccurate reporting and non-compliance with regulatory requirements, declining ethics and huge non-performing insiderrelated credits. Others included over-dependence on public sector deposits and foreign exchange trading as well as the neglect of small and medium scale enterprises. Thus handicapped, the Nigerian banking industry was not in a position to meet the nation's ideal of a strong, competitive and stable banking industry (CBN, 2007).

\section{Outcome of the Banking Sector Restructuring in Nigeria}

The banking sector reforms focused on strengthening and consolidating the banking industry, and ended on December 31, 2005. At the conclusion of the exercise, the sector witnessed a lot of changes in terms of structure, size and ownership of banks. These changes included: fewer but larger banking organizations; large inflow of capital to the banking sector; improved international ranking for Nigerian banks; relatively high capital base; greater capability to operate as universal banks; and dilution of ownership among others.

\section{Methodological Issues}

Primary data was obtained via questionnaires administered on 372 randomly selected management staff of the twenty-one banks covered in this study. Respondents were allowed to make multiple responses. The questions were based on the determinants of corporate restructuring in the Nigerian banking industry. The secondary data used in this study were collected from the Annual Reports and Accounts of the various banks deposited at the Nigerian Stock Exchange and included the profitability ratios; leverage ratios and shareholders' ratios of all the 21 banks listed on the Nigerian Stock Exchange (see appendix I). The data set in this group was entirely quantitative in nature and measured on the ratio scale. The data were analysed, using a descriptive statistics (Difference of Means) method, to determine how each variable of interest behaved in the period before the adoption of the restructuring method (2000 - 2004) and after the adoption of the restructuring method (2005-2009). The aim was to measure the difference between the pre-consolidation performance and the post-consolidation performance of the banks in Nigeria. This analysis was carried out using the EZAnalyze - Data Analysis for Educators (version 3.0), an "Add in" to Microsoft's Excel developed by Tim Poynton in 2004 and updated in 2007. (EZAnalyze is available for download at (http://www.ezana lyze.com)

\section{Definition of Variables}

For the purpose of this analysis, merger, acquisition and capital restructuring are the independent variables while the ratio of market value to the book value of shares, used as the proxy for shareholder value, is the dependent variable. The assumption here is that an increase in the market-value-to-bookvalue ratio translates to an increase in shareholder value. This is also consistent with the market-valueto-book-value theory of shareholder value. In order to measure the impact of the corporate restructuring 
on the creation of shareholder value, profitability, dividend and leverage ratios are used. They are defined as follows:

\section{Profitability ratios}

a. Net interest margin was defined as the ratio of net interest income to total assets.

b. Yield on earning assets was defined as ratio of net interest income to income-generating assets.

c. Return on equity was defined as the ratio of profit before tax and preference dividend to equity (shareholders' funds) (Olowe, 1997 and Wood and Sangster, 2005).

d. Efficiency ratio was defined as the ratio of operating expenses to operating income (CBN, 2005).

\section{Stock market (dividend) ratios}

a. Dividend per share was defined as the ratio of the total ordinary dividend to the number of ordinary shares in issue.

b. Dividend cover was defined as the ratio of the net profit (or loss) attributable to ordinary shareholders to net dividend on ordinary shares (Wood and Sangster, 2005).

c. Dividend yield was defined as the ratio of gross dividend per share to market price per share (Wood and Sangster, 2005).

\section{Financial structure (leverage) ratios}

a. Debt ratio was defined as the ratio of the total liabilities to total assets (Wood and Sangster, 2005).

b. Capital gearing ratio was defined as the ratio of prior charge capital to total capital (Wood and Sangster, 2005).

c. Debt-Equity ratio was defined as the ratio of prior charge capital to ordinary share capital and reserves (shareholders' funds) (Wood and Sangster, 2005).
The data were analyzed in a tabular arrangement using the EZAnalyze software (version 3.0). The steps involved in the data analysis are as follows:

1. For each of the restructuring options (mergers, acquisitions and capital restructuring), the values of the research variables were determined (computed) for the periods before the consolidation exercise (2000-2004) and the periods after the consolidation exercise (2005-2009);

2. The average values of the ratio of market value of shares to the book value of shares for all the banks under each restructuring option were computed for the pre- and post-consolidation periods;

3. The total values of all the research variables were computed for the pre-consolidation period as 'Pre-Total'. The same was done for the post-consolidation period as 'Post-Total'.

4. A difference score was then calculated which showed the difference between the Postconsolidation Total and the Pre-consolidation Total. This score was described as 'Period Difference'.

5. Another difference score was computed which showed the difference between the preconsolidation market value of shares and the post- consolidation market value of shares. This difference was described as 'SVC Difference'.

6. Next, the mean values for all the variables were computed.

Based on the results obtained, the researcher was able to determine the impact of each restructuring option on the shareholder value as well as which restructuring option, which had the greatest (and the least) impact on the creation of shareholder value. 


\section{Data}

21 of the questionnaires administered were either not returned or badly completed. The responses based on the 351 good questionnaires are presented in Figure 1.

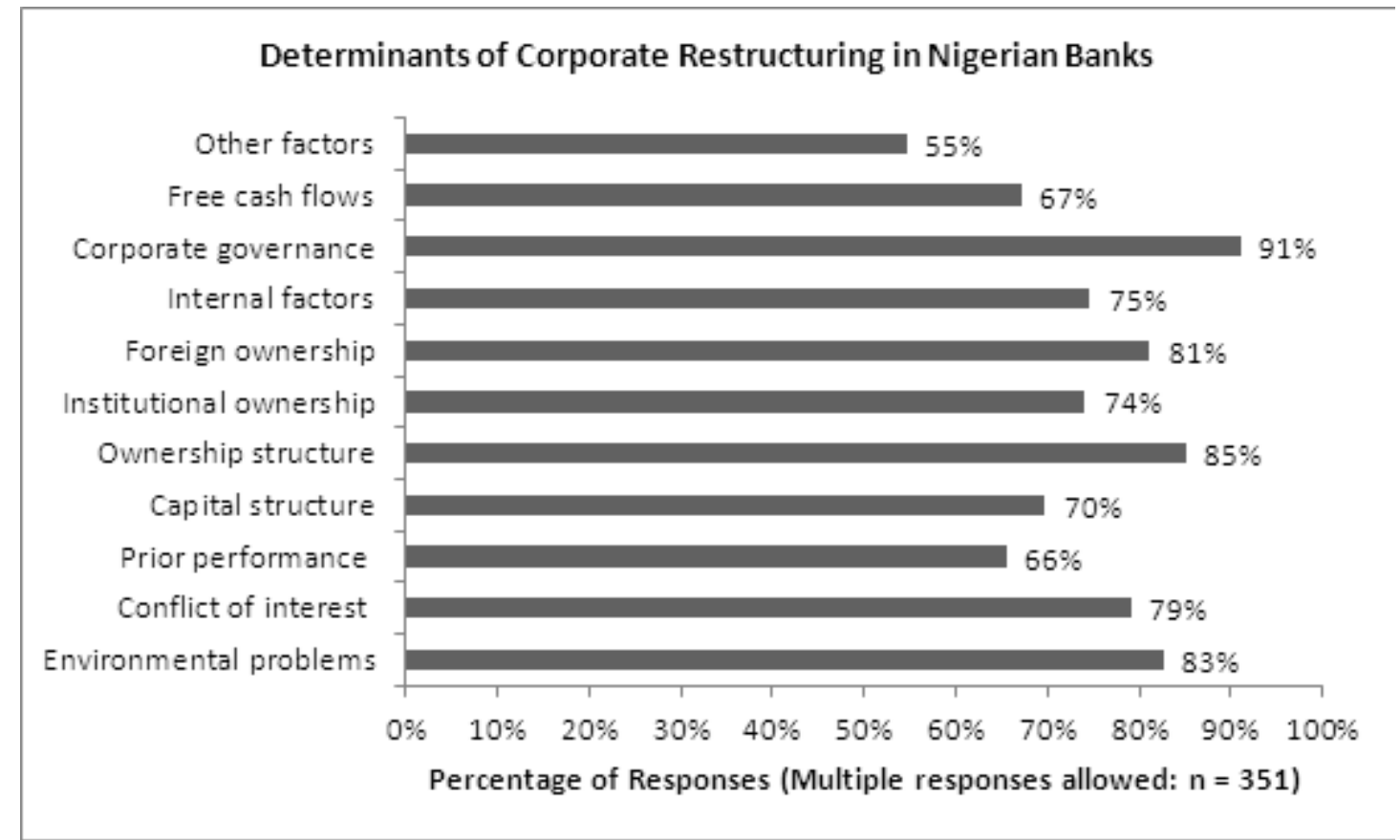

Figure 1: Percentage of responses on the determinants of corporate restructuring in the Nigerian banking industry

Source: Questionnaire

\section{Computation of the Difference in Sample Means (Descriptive Statistics)}

The data for analysis are presented in appendix II. The computer outputs of the EZAnalyze computations are presented in Table 1 below.

Table 1: EZAnalyze Results Report

EZAnalyze Results Report - Descriptive Statistics - Mergers

\begin{tabular}{|c|c|c|c|c|c|c|}
\hline & PRE-TOTAL & POST-TOTAL & PRE- SVC & POST- SVC & $\begin{array}{c}\text { PERIOD } \\
\text { DIFFERENCE }\end{array}$ & $\begin{array}{c}\text { SVC } \\
\text { DIFFERENCE }\end{array}$ \\
\hline N Valid: & 9 & 9 & 9 & 9 & 9 & 9 \\
\hline N Missing: & 0 & 0 & 0 & 0 & 0 & 0 \\
\hline Mean: & 21.334 & 152.006 & 5.164 & 15.798 & 130.672 & 10.634 \\
\hline Std. Dev: & 12.969 & 345.593 & 4.437 & 13.568 & 341.844 & 11.018 \\
\hline
\end{tabular}


EZAnalyze Results Report - Descriptive Statistics - Acquisitions

\begin{tabular}{|c|c|c|c|c|c|c|}
\hline & PRE-TOTAL & POST- TOTAL & PRE- SVC & POST- SVC & PERIOD & SVC \\
\hline N Valid: & 9 & 9 & 9 & 9 & 9 & 9 \\
\hline N Missing: & 1 & 1 & 1 & 1 & 1 & 1 \\
\hline Mean: & 26.293 & 85.738 & 15.241 & 30.382 & 59.445 & 15.141 \\
\hline Std. Dev: & 11.389 & 140.050 & 13.128 & 17.782 & 141.139 & 6.609 \\
\hline
\end{tabular}

EZAnalyze Results Report - Descriptive Statistics - Capital Restructuring

\begin{tabular}{|c|c|c|c|c|c|c|}
\hline & PRE-TOTAL & POST- TOTAL & PRE- SVC & POST- SVC & $\begin{array}{c}\text { PERIOD } \\
\text { DIFFERENCE }\end{array}$ & $\begin{array}{c}\text { SVC } \\
\text { DIFFERENCE }\end{array}$ \\
\hline N Valid: & 3 & 3 & 3 & 3 & 3 & 3 \\
\hline N Missing: & 13 & 13 & 13 & 13 & 13 & 13 \\
\hline Mean: & 25.308 & 238.745 & 12.915 & 39.331 & 213.437 & 26.415 \\
\hline Std. Dev: & 2.403 & 181.871 & 7.749 & 15.540 & 181.667 & 7.916 \\
\hline
\end{tabular}

EZAnalyze Results Report - Descriptive Statistics - Combined Results

\begin{tabular}{|c|c|c|c|c|c|c|}
\hline & PRE-TOTAL & POST- TOTAL & PRE- SVC & POST- SVC & $\begin{array}{c}\text { PERIOD } \\
\text { DIFFERENCE }\end{array}$ & $\begin{array}{c}\text { SVC } \\
\text { DIFFERENCE }\end{array}$ \\
\hline N Valid: & 21 & 21 & 21 & 21 & 21 & 21 \\
\hline N Missing: & 1 & 1 & 1 & 1 & 1 & 1 \\
\hline Mean: & 24.027 & 135.997 & 10.590 & 25.410 & 111.970 & 14.820 \\
\hline Std. Dev: & 11.205 & 248.521 & 10.325 & 17.494 & 246.890 & 10.020 \\
\hline
\end{tabular}

\section{Interpretation of Results}

The merger method: EZAnalyze Results Report shows that under the merger method, the overall performance of the Nigerian banking industry, measured by the profitability, dividend and leverage ratios, increased significantly by 130.67 points on the average while the shareholder value created increased significantly by 10.63 points on the average from the pre-consolidation period to the postconsolidation period. On this basis therefore, we that there is a significant difference in shareholder value creation between merged and non-merged banks in the Nigerian banking industry.

The acquisition method: EZAnalyze Results Report shows that under the acquisition method, the overall performance of the Nigerian banking industry, 
measured by the profitability, dividend and leverage ratios, increased, though not very significantly, by 59.45 points on the average while the shareholder value created increased significantly by 15.14 points on the average from the pre-consolidation period to the post-consolidation period. On this basis therefore, we that there is a significant difference in shareholder value creation between acquired and non-acquired banks in the Nigerian banking industry.

The capital restructuring method: EZAnalyze Results Report shows that under the capital restructuring method, the overall performance of the Nigerian banking industry, measured by the profitability, dividend and leverage ratios, increased significantly by 213.44 points on the average while the shareholder value created increased significantly by 26.42 points on the average from the preconsolidation period to the post-consolidation period. On this basis therefore, we that there is a significant difference in shareholder value creation between restructured and non-restructured banks in the Nigerian banking industry.

Comparison of results: When compared with one another, EZAnalyze Results Report shows that the capital restructuring method has the greatest positive impact on the creation of shareholder value in the Nigerian banking industry.

\section{Research Findings}

Our findings based on the merger method show that mergers have a significant impact on value creation in the Nigerian banking industry. This finding contradicts the earlier findings of Berger, Saunders, Scalise, and Udell (1998) and Cuervo (1999: 19) who argue that "the existence of non-explicit reasons", among other things, account for why there is no difference between firmswhether acquired or merged - in terms of value creation. It also negates the finding of Burns et al. (1998: 185-92), who argue that:
Only those which occur between utilities operating in different primary lines of business ("bundling" mergers) experience significant increases in firm value. Consistent with other studies, conglomerate mergers lead to a substantial decrease in firm value. Horizontal and vertical mergers lead to insignificant wealth gains.

The finding, however, confirms the findings of Banerjee and Eckard (1998), Hotchkiss and Mooradian (1998) and Mahmood and Mohamad (2007) whose studies confirm the assertion that mergers have a significant impact on value creation.

Our findings based on the acquisition method show that acquisitions have a significant impact on value creation in the Nigerian banking industry. This finding is consistent with the findings of Seth, Song and Pettit (2000) and BCG (2005). BCG (2005:5) argues: "acquisitions can create considerable value and half of top performers' growth derives from acquisitions". All these studies confirm the assertion that acquisitions have a significant impact on value creation.

Our findings based on the capital restructuring method show that capital restructuring has a significant impact on value creation in the Nigerian banking industry. This finding concurs with the following arguments as put forward by BPP (2009): The effects of changes in the financial policy of a firm is directly observable in its beta (systematic risk); The market response to financial reconstruction of a firm can be estimated from the behaviour of its share prices; and The causes of the improvement following financial restructuring are reportedly benign and cannot be attributed to lay-offs of employees - rather the increased efficiency of operations coupled with improved control of capital expenditure seem to account for much of the difference. All these arguments confirm the assertion that capital restructuring has a significant impact on value creation. 


\section{Conclusion and Recommendations}

This study has examined the impact of corporate restructuring on the creation of shareholder value in the Nigerian banking industry. Based on the secondary data collected and analysed in respect of the 21 banks, it has been established that in the Nigerian banking industry, three methods of restructuring have very significant impacts on value creation, but the capital restructuring method has the greatest positive impact on the creation of shareholder value. The study also found that most banks in the industry have to restructure as a result of problems like weaknesses in corporate governance; weak ownership structure, conflict of interest between management and shareholders, environmental problems, and internal problems. The findings of this study imply that banks involved in mergers are not likely to create as much or enhance value for their shareholders like their counterparts in the industry that were involved in acquisition and/ or capital restructuring.

Based therefore, on the findings of the study, the following recommendations are being made:

Firstly, industry regulators and practitioners seeking to create value for shareholders should focus on capital restructuring and acquisition as the most appropriate techniques of corporate restructuring and focus less on merger, as much as possible;

Secondly, future policies should focus on the strategies that favour growth, expansion and performance improvement which position the banks for competition and other challenges in the industry;

Thirdly, industry regulators and operators should also strive to encourage practices in the industry which seek to eliminate or reduce problems including but not limited to weaknesses in corporate governance; weak ownership structure, conflict of interest between management and shareholders, environmental problems, and internal problems in the Nigerian banking industry; and
Finally, policy makers for the Nigerian banking industry should put in place policies, which encourage local and foreign participation and adherence of all banks to international best practices.

\section{References}

Aghion, P. and Stein, J. (2006). Growth vs. margins: destabilizing consequences of giving the stock market what it wants, Working Paper, Harvard University

Athanasoglou, P. P., Brissimis, S. N. and Delis, M. D. (2005). Bank-Specific, Industry-Specific and Macroeconomic Determinants of Bank Profitability; Bank of Greece Working Paper, No. 25

Banerjee, A. and Eckard, E. W. (1998). Are megamergers anticompetitive? Evidence from the first great merger wave; RAND-Journal-of-Economics; 29(4): 803-27, winter

Barajas, A., Steiner, R. and Salazar, N. (1999): Interest spreads in banking in Colombia 1974-96; IMF Staff Papers, (46) pp 196-224

Barlow, J. and Maul, D. (2000). Emotional value: creating strong bonds with your customers, San Francisco: Berrett-Koehler Publishers, Inc. 300 pp. Downloaded from: www.tmius.com/ eval3.htm on $3^{\text {rd }}$ April, 2009.

Bartram, S. M. (2000). Corporate risk management as a lever for shareholder value creation; Financial Markets, Institutions and Instruments, 9(5)

Ben-Naceur, S. and Goaied, M. (2001). The determinants of the Tunisian deposit banks' performance; Applied Financial Economics, 11: 317-19

Berger, A. N., Saunders, A., Scalise, J. M. and Udell, G. F. (1998). The effects of bank mergers and acquisitions on small business lending; Journal of Financial Economics; 50(2): 187-229, November. Available at http://www.elsevier.com/ homepage/sae/econbase/finec 
Boston Consulting Group (2003). Succeeding with growth: creating value in banking 2003; BCG Report

Boston Consulting Group (2005). Succeeding with growth: creating value in banking 2005; BCG Report

Boston Consulting Group (2006). Succeeding with growth: creating value in banking 2006; BCG Report

Boston Consulting Group (2007). Creating value in banking 2007, bigger, better banking: emerging titans, soaring profitability, and continued growth; BCG Report

Boston Consulting Group (2008). Creating value in banking 2008: managing shareholder value in turbulent times; BCG Report

Bounfour, A. (2000). Le valeur dynamique du capital immateriel (the dynamic nature of intangible capital), Revue Francaise de Gestion; 0 (130), September - October

Bowman, E. H., Singh, M. U. and Bhadury, R. (1999). When does restructuring improve economic performance? California Management Review, 41 (2): $33-54$

BPP (2009). ACCA: advanced financial management ( ${ }^{\text {rd }}$ ed.), London: BPP Learning Media Ltd.

Brealey, R. A. and Myers, S. C. (1996). Principles of corporate finance ( $5^{\text {th }}$ ed.); New York: McGrawHill Inc. 998p

Brealey, R. A., Myers, S. C. and Marcus, A. J. (1999). Fundamentals of corporate finance $\left(2^{\text {nd }}\right.$ ed. $)$, Boston: Irwin/McGraw-Hill

Brownbridge, M. (1998). The causes of financial distress in local banks in Africa and implications for prudential policy; United Nations Conference on Trade and Development (UNCTAD), Geneva No 132 March: Downloaded from: http:// www.unicc.org/unctad/en/pressref/prdis.htm
Burns, R. and Others (1998). Value Creation in bundling utility mergers: a corporate focus anomaly; Journal of Energy Finance and Development; 3(2): 185-92

Caby, J. and Others (1996). Strategie et finance: le processus de creation de valeur. Revue Francaise de Gestion (With English Summary); 108, 49-56

Central Bank of Nigeria (2006). Code of corporate governance for banks in Nigeria post consolidation; Abuja: Central Bank of Nigeria

Chander, S. and Aggarwal, P. (2007). Determinants of corporate growth: an empirical study of Indian drugs and pharmaceutical industry. The Icfaian Journal of Management Research 6 (10): 50-70, October. Available at SSRN: http://ssrn.com/ abstract $=1035702$

Chen, S. and Dodd, J. L. (1997). usefulness of operating income, residual income, and EVA ${ }^{\mathrm{TM}}$ : a valuerelevance perspective, Working Paper, Social Science Research Network.

Cuervo, A. (1999). Reasons for mergers and acquisitions: organizational and non-explicit factors as determinants of success; New York University, Salomom Center Working Paper S/99/ 23, June p.19

de-Andres-Alonso, P., Azozfra-Palenzuel, V. and Rodriguez-Sanz, J. A. (2000). Endeudamiento, oportunidades de crecimiento y estructura contractual: un contraste empirico para el caso espanol. (Debt, growth opportunities and contractual structure: a Spanish firms analysis); Investigaciones-Economicas, 24 (3), September

Echebarria-Miguel, M. C.and Barrutia-Legarreta, J. M. (1999). De valor en banca (Creation of value in banking system); Informacion-ComercialEspanola-Revista-de-Economia; 0 (775), Dec 1998Jan 1999

Faccio, M., Masulis, R. and McConnell, J. (2005). Political connections and government bailouts, Journal of Finance. 
Fairfield, P. M., Ramnath, S. and Yohn, T. L. (2005). Does industry-level analysis improve profitability and growth forecasts? Working Paper Series. Available at SSRN: http://ssrn.com/ abstract $=589361$

Fama, E. F. and French, K. R. (2007). The anatomy of value and growth stock returns, Financial Analysts Journal, 63 (6). Available at SSRN: http:// ssrn.com/abstract=1071124

Fernández, P., Valuing companies by cash flow discounting: ten methods and nine theories (December 27, 2006), EFMA 2002 London Meetings. Available at SSRN: http://ssrn.com/ abstract $=256987$

Filatotchev, I. R., Buck, T. and Wright, M. (1996). Corporate restructuring in Russia privatization: implications for U.S. investors; California Management Review, 38 (2)

Fruhan, W. E. (1979). Financial strategy: studies in the creation, transfer and destruction of shareholder value. Homewood, IL: R. D. Irwin

Fuller, J. and Jensen, M. (2002). Just say no to Wall Street, Journal of Applied Corporate Finance, Forthcoming in Spring

García-Herrero, A. (2003). Determinants of the Venezuelan banking crisis of the mid-1990s: an event history analysis, MIMEO Economía Mexicana, Vol. XIV, No. 1, Primer Trimestre, 2005, December. Available at SSRN: http://ssrn.com/ abstract $=1433238$

Ghoshal, S., Hahn, M. and Moran, P. (1997). Management competence, firm growth and economic progress; INSEAD Working Papers, 97/ 21/SM, February

Gilson, S. C. (1998). Course overview: creating value through corporate restructuring; Boston: Havard Business School

Gleason, K. C., Mathur, I. and Wiggins III, R. A. (2003). Evidence on value creation in the financial services industries through the use of joint ventures and strategic alliances; The Financial Review 38(2), May. Available at www.ssrn.com

Glushkov, D., (2007). The importance of catering incentives: growth or profitability? Working Paper Series. Available at SSRN: http://ssrn.com/ abstract $=943439$

Goddard, J., Molyneux, P. and Wilson, J. O. S. (2004). The profitability of European banks: a crosssectional and dynamic panel analysis; Manchester School, 72 (3): 363-381

Gong, G., Louis, H. and Sun, A. X. (2007). Earnings management and firm performance following open-market repurchases, Journal of Finance, Forthcoming. Available at SSRN: http://ssrn.com/ abstract $=962611$

Hailemariam, S. (2001). Corporate value creation, governance and privatization: restructuring and managing enterprises in transition - the case of Eritrea. Unpublished Ph. D Thesis

Hamilton, R. (1977). An introduction to merchandize In: G. C., Biddle, R. M. Bowen, and J. S. Wallace (1997) Evidence on the relative and incremental information content of $\mathrm{EVA}^{(\mathrm{TM})}$, residual income, earnings and operating cash flow, Journal of Accounting and Economics 24(3)

Hellwig, K. (1998). Creating value; International Review of Economics and Finance, 7(2)

Katib, M. N. (2000). Market structure and performance in the Malaysian banking industry: a robust estimation. Working Paper Series available at www.ssrn.com

Kazmi, A. (1992). Business policy, New Delhi: Tata McGraw-Hill

Koller, T. (1994). What is value based management? The Mckinsey Quarterly No. 3

Levesque, M. and Minniti, M. (2007). Short term sacrifices for long term benefits: a look at high growth firms, Babson College Entrepreneurship Research Conference (BCERC) 2007; Frontiers of 
Entrepreneurship Research Available at SSRN: http://ssrn.com/abstract=1064921

Lockett, A., Wiklund, J. and Davidsson, P. (2007). Reexamining and extending Penrose's growth theory: updating Penrose for the 21st century, Babson College Entrepreneurship Research Conference (BCERC) 2007; Frontiers of Entrepreneurship Research Available at SSRN: http://ssrn.com/abstract=1059841

Mahmood, W. M. and Mohamad, R.(2007). Does operating performance really improve following mergers: the case of Malaysian banks; ICFAI Journal of Merger and Acquisition. Downloaded from: Social Science Electronic Publishing Inc. at http://www.ssrn.com

Maimako, S. S. (2010). Principles of corporate governance. Abuja: Eriba Publishing Company, $232 p$

Marshall, A. (1890). Principles of economics. In: G. C., Biddle, R. M. Bowen, and J. S. Wallace (1997) Evidence on the relative and incremental information content of $\mathrm{EVA}^{(\mathrm{TM})}$, residual income, earnings and operating cash flow, Journal of Accounting and Economics 24 (3)

Martin, X. (2007). Inter-temporal persistence and mispricing of accruals and growth in long-term net operating assets: growth or accounting distortions? Working Paper Series, March. Available at SSRN: http://ssrn.com/ abstract $=975850$

McCarthy, D. J., Minichiello, R. J. and Curran, J. R. (2000). Business policy and strategy ( $4^{\text {th }}$ ed.), Homewood: Richard D. Irwin

Moran, P. and Ghoshal, S. (1997). Value creation by firms; INSEAD Working Papers: 97/19/SM, February

Muhammed, R. (2005). Understanding mergers and acquisitions, Business Day, February 17

Naceur, S. B. (2003). The determinants of the Tunisian banking industry profitability: panel evidence, Tunis; ERF/Working Paper Series, October
Naceur, S. B. and Goaied, M. (2003). The value creation process in the Tunisian Stock Exchange; API/ Working Paper Series No 9903; October

Nunamaker, J., Briggs, R. O. , Vreede, G. D. and Sprague, R. (2001). Enhancing organizations' intellectual bandwidth: the quest for fast and effective value creation; Journal of Management Information Systems (special Issue) 17 (3): $3-8$, winter. Retrieved from: http://jmis.bentley.edu/ issues/Winter_2001/index.html on Tuesday, January $15^{\text {th }} 2008$

Olowe, R .A. (1997). Financial management: concepts, analysis and capital investments. Lagos: Briely Jones Nig. Ltd.

Osho, M. (2004). Consolidation through mergers and acquisitions: the African experience; Conference Proceedings on Consolidation of Nigeria's Banking Industry, Abuja: Central Bank of Nigeria.

Pandey, I. M. (2002). Financial Management ( $8^{\text {th }}$ ed.); New Delhi: VIKAS Publishing PVT Ltd. 1226p

Pariente, S. (2000). Rendement boursier, creation de valeur et donnees comptables: une etude sur le marche franchais (With English summary); Revue Finance Controle Strategie, 3 (3), September

Pearce, J. A. and Robinson, R. B. (2000). Strategic management: formulation, implementation and control ( $7^{\text {th }}$ ed.), Boston: Irwin/McGraw-Hill

Penrose, E. T. (1959). The theory of growth of the firm, Blackwell: Oxford

Pierrat, C. and Martory, B. (2000). Les specificites du pilotage de i'mmateriele (unique aspects of managing intangible assets); Revue Francaise de Gestion, 0 (10), September - October

Poynton, T. A. (2007). Ezanalyze (version 3.0) [Computer software and manual]. Retrieved from: http://www.ezanalyze.com

Qureshi, S., and Briggs, R. O. (2003). Revising the intellectual bandwidth model and exploring its 
use by management team, Proceedings of the 36th Hawaii International Conference on System Sciences (HICSS'03), IEEE.

Ramezani, C. A., Soenen, L. A. and Jung, A. R. (2001). Growth, corporate profitability, and shareholder value creation, Working Paper Series, Available at SSRN: http://ssrn.com/abstract=304880 or DOI: $10.2139 /$ ssrn. 304880

Rappaport, A. (1987): Corporate performance standards and shareholders value; The Journal of Business Strategy, 28-38

Rossi, M. J. (2006). Determinants of the relationship between strategic performance and shareholder's value creation: beyond financials; April. Available at SSRN: http://ssrn.com/ abstract $=933300$

Sadka, G. and Sadka, R. (2008). Predictability and the earnings-returns relation, Journal of Financial Economics, Forthcoming in November. Available at SSRN: http://ssrn.com/abstract=1307089

Salem, H. Organizational performance management and measurement: the Lebanese experience; Paper presented at the Expert Consultative Meeting on Public Administration and Public Accounting Development with stress on Electronic Tools jointly with The Innovation of Public Administration in the Euro-Mediterranean Region (UNDESA), Beirut 1-3 July, 2003. United Nations Economic and Social Commission for Western Asia

Sanyal, P. and Shankar, R. (2005). Financial sector reforms and bank efficiency in developing countries: lessons from India; Working Paper Series. Available at www.ssrn.com

Seligman, E. R. A. (1905). Principles of Economics, New York pp. 179-82 and 192-93 downloaded from: http://spartan.ac.brocku.ca/\%7Elward/ Anderson_1911/Anderson_1911_note.html on Friday, March 27, 2009

Seth, A., Song, K. P. and Pettit, R. (2000): Synergy, managerialism or hubris? An empirical examination of motives for foreign acquisition of U. S. firms; Journal of International Business Studies; 31(3), $3^{\text {rd }}$ Quarter.

Shivdasani, A and Kang, J. K. (1996). Corporate restructuring during performance declines in Japan; Working Paper Series. Available at www.ssrn.com

Slater,S. F. and Zwirlein, T. J. (1996). The structure of financial strategy: patterns in financial decision making; Managerial-and-Decision-Economics; 17(3), May-June

Smith, A. (1776). In Cannan, E. (Eds.) The wealth of nations, New York, NY: Modern Library, (1937)

Stern, Stewart \& Co. (1997). The EVA Company downloaded from: www.sternstewart. com/ publications/art_real_key.html on Friday, March 27,2009

Umoh, P. N. (2004). Capital restructuring of banks: conceptual framework; Conference Proceedings on Consolidation of Nigeria's Banking Industry, Abuja: Central Bank of Nigeria.

Van Horne, J. C. (2002). Financial management and policy (12 ${ }^{\text {th }}$ ed.) New Delhi: Prentice-Hall of India $814 p$

Varelas, E., Karpetis, G. C., and Konikarpeti, G. (2004). Effects of operational cost on bank profitability and bank clients: a methodical approach; Journal of Financial Management and Analysis 17(1): 54-

6. Available at www.ssrn.com

Vélez-Pareja, I. (1999). Construction of free cash flows a pedagogical note Part I, Working Paper, Social Science Research Network.

Vélez-Pareja, I. (2000). Construction of free cash flows: a pedagogical note. Part II, Working Paper, Social Science Research Network.

Velez-Pareja, I. (2001): Value creation and its measurement: a critical look at EVA; Bogotá, School of Industrial Engineering 
Weissenrieder, F. (1997). Value based management: economic value added or cash value added?, Working Paper, Social Science Research Network.

Young, J. O. (2001). Art and knowledge, London: Routledge; $180 p$

\section{Authors' Profile}

Dr Seddi Sebastian Maimako, had his university education at the University of Jos, in North Central Nigeri and holds a PhD in Management. He is an associate Professor in the Department of Business Administration, University of Jos and is also the Deputy Dean Faculty of Management Sciences. He is also a member of the Institute of Chartered Accountants of Nigeria and is in the editorial board of many journals in Nigeria. He is also an external examiner to many Universities and other tertiary Institutions in Nigeria and Ghana. He has published in many journals.
Oladele Olugbenga Kolawole, is an Associate of the Institute of Chartered Accountants of Nigeria (ICAN) and Nigerian Institute of Management (NIM) (Chartered). He graduated from the University of Jos with a B.sc (Hons) in Accounting and followed this up with two Postgraduate degrees, MSc (Accounting and Finance) and an MBA (Finance) at the Ahmadu Bello University, Zaria and University of Jos respectively. $\mathrm{He}$ is presently studying for a Doctorate Degree in Management. He lectured at the Kaduna Polytechnic for 15 years after which he left in 2008 to join the Nigerian Defence Academy, also as a lecturer. He had earlier worked in Central Bank of Nigeria as an Accounts Supervisor and Datum Construction Nigeria Limited as Accountant and Internal Auditor at various times. His training in research methodology has both foreign and local dimensions and inputs. He has made several publications in academic journals. He is also a well known expert in Accounting Systems and Business Process Systems Design, Computerization and Implementation.

APPENDIX I: The 21 banks selected for the study were listed on the Nigerian Stock Exchange

\begin{tabular}{|c|l|l|}
\hline S/No & \multicolumn{1}{|c|}{ Name of Bank } & \multicolumn{1}{c|}{ Members of the Group } \\
\hline & A: MERGERS & \\
\hline 1 & FinBank PLC & First Atlantic Bank, Inland Bank and NUB International Bank \\
\hline 2 & Sterling Bank PLC & $\begin{array}{l}\text { Magnum Trust Bank, NBM Bank, NAL Bank, Indo-Nigerian Merchant Bank } \\
\text { and Trust Bank of Africa }\end{array}$ \\
\hline 3 & Stanbic-IBTC PLC & Stanbic Bank, IBTC and Chartered Bank \\
\hline 4 & United Bank for Africa PLC & $\begin{array}{l}\text { United Bank for Africa, Standard Trust Bank, Continental Trust Bank and } \\
\text { Commercial Trust Bank }\end{array}$ \\
\hline 5 & Fidelity Bank PLC & Fidelity Bank, FSB International Bank and Manny Bank \\
\hline 6 & Bank PHB PLC & Platinum Bank and Habib Nigerian Bank \\
\hline 7 & Skye Bank PLC & $\begin{array}{l}\text { Prudent Bank, Bond Bank, Cooperative Bank, Reliance Bank, and EIB } \\
\text { International Bank }\end{array}$ \\
\hline 8 & Spring Bank PLC & $\begin{array}{l}\text { Guardian Express Bank, Citizens Bank, Omega Bank, Trans International } \\
\text { Bank, Fountain Trust Bank and ACB International Bank }\end{array}$ \\
\hline 9 & Unity Bank PLC & $\begin{array}{l}\text { New African Merchant Bank, Tropical Commercial Bank, Pacific Bank, } \\
\text { Centre Point Bank, First Intestate Bank, Societe Bancaire, NNB } \\
\text { International Bank, Intercity Bank and Bank of the North. }\end{array}$ \\
\hline
\end{tabular}




\section{B: ACQUISITIONS}

\begin{tabular}{|c|c|c|}
\hline 10 & Diamond Bank Nigeria PLC & Diamond Bank Nigeria, and Lion Bank \\
\hline 11 & First Bank of Nigeria PLC & First Bank, FBN Merchant Bankers, and MBC International \\
\hline 12 & Union Bank of Nigeria PLC & Union Bank, Union Merchant Bank, \\
\hline 13 & Access Bank PLC & $\begin{array}{l}\text { Broad Bank and Universal Trust Bank } \\
\text { Access Bank, Capital Bank and Marina Bank }\end{array}$ \\
\hline 14 & Wema Bank PLC & Wema Bank and National Bank \\
\hline 15 & Intercontinental Bank PLC & $\begin{array}{l}\text { Intercontinental Bank, Equity Bank, } \\
\text { Global Bank and Gateway Bank }\end{array}$ \\
\hline 16 & Afribank PLC & Afribank and Afribank (Merchant Bankers) \\
\hline 17 & First City Monument Bank & $\begin{array}{l}\text { First City Monument Bank, Cooperative Development Bank, } \\
\text { Nigerian- American Merchant Bank and Midas Bank }\end{array}$ \\
\hline 18 & Oceanic Bank International PLC & Oceanic Bank International and International Trust Bank \\
\hline
\end{tabular}

\section{C: CAPITAL RESTRUCTURING}

\begin{tabular}{|c|l|l|}
\hline 19 & Guaranty Trust Bank PLC & Guaranty Trust Bank PLC \\
\hline 20 & Zenith International Bank PLC & Zenith International Bank PLC \\
\hline 21 & ECOBANK Nigeria PLC & ECOBANK Nigeria PLC \\
\hline
\end{tabular}

APPENDIX II: Data for the Study

\section{MERGERS}

\begin{tabular}{|c|c|c|c|c|c|c|c|c|c|c|c|c|c||}
\hline ID & Bank & $\begin{array}{c}\text { Pre } \\
\text { Profita } \\
\text { bility } \\
\text { Ratios }\end{array}$ & $\begin{array}{c}\text { Pre } \\
\text { Divid } \\
\text { end } \\
\text { Ratios }\end{array}$ & $\begin{array}{c}\text { Pre } \\
\text { Lever } \\
\text { age } \\
\text { Ratios }\end{array}$ & $\begin{array}{c}\text { Post } \\
\text { Profit } \\
\text { ability } \\
\text { Ratios }\end{array}$ & $\begin{array}{c}\text { Post } \\
\text { Divide } \\
\text { end } \\
\text { Ratios }\end{array}$ & $\begin{array}{c}\text { Post } \\
\text { Lever } \\
\text { age } \\
\text { Ratios }\end{array}$ & $\begin{array}{c}\text { Pre } \\
\text { Total }\end{array}$ & $\begin{array}{c}\text { Post } \\
\text { Total }\end{array}$ & $\begin{array}{c}\text { Pre } \\
\text { SVC }\end{array}$ & $\begin{array}{c}\text { Post } \\
\text { SVC }\end{array}$ & $\begin{array}{c}\text { Period } \\
\text { Differe } \\
\text { nce }\end{array}$ & $\begin{array}{c}\text { SVC } \\
\text { Differe } \\
\text { nce }\end{array}$ \\
\hline 1 & FNB & 0.96 & 11.47 & 6.46 & 0.92 & 22.77 & 10.01 & 18.89 & 33.70 & 3.34 & 10.59 & 14.81 & 7.25 \\
\hline 2 & STLB & 0.81 & 29.99 & 6.08 & 0.52 & 35.37 & 9.64 & 36.88 & 45.53 & 7.48 & 8.47 & 8.65 & 0.99 \\
\hline 3 & ST-IB & 0.64 & 10.88 & 6.81 & 0.74 & 24.39 & 23.47 & 18.34 & 48.60 & 8.52 & 17.74 & 30.26 & 9.22 \\
\hline 4 & UBA & 1.22 & 12.66 & 18.28 & 0.90 & 21.35 & 1050.36 & 32.17 & 1072.62 & 14.07 & 49.04 & 1040.45 & 34.97 \\
\hline 5 & FDLT & 0.89 & 12.23 & 7.89 & 0.70 & 26.21 & 1.50 & 21.01 & 28.41 & 5.75 & 9.26 & 7.41 & 3.51 \\
\hline 6 & PHB & 0.17 & 1.27 & 1.76 & 0.57 & 15.22 & 5.67 & 3.20 & 21.47 & 0.00 & 22.33 & 18.26 & 22.33 \\
\hline 7 & SKYE & 0.77 & 13.98 & 18.21 & 0.80 & 21.84 & 23.74 & 32.97 & 46.39 & 3.68 & 12.43 & 13.42 & 8.76 \\
\hline 8 & SPRG & 1.09 & 20.19 & 7.28 & 0.22 & 7.91 & 1.18 & 28.56 & 9.30 & 3.64 & 6.87 & -19.25 & 3.23 \\
\hline 9 & UNITY & 0.00 & 0.00 & 0.00 & 0.01 & 45.80 & 16.22 & 0.00 & 62.04 & 0.00 & 5.46 & 62.04 & 5.46 \\
\hline
\end{tabular}




\section{ACQUISITIONS}

\begin{tabular}{|c|c|c|c|c|c|c|c|c|c|c|c|c|c|}
\hline ID & Bank & $\begin{array}{c}\text { Pre } \\
\text { Profita } \\
\text { bility } \\
\text { Ratios }\end{array}$ & $\begin{array}{c}\text { Pre } \\
\text { Divid } \\
\text { end } \\
\text { Ratios }\end{array}$ & $\begin{array}{c}\text { Pre } \\
\text { Lever } \\
\text { age } \\
\text { Ratios }\end{array}$ & $\begin{array}{c}\text { Post } \\
\text { Profit } \\
\text { ability } \\
\text { Ratios }\end{array}$ & $\begin{array}{c}\text { Post } \\
\text { Divide } \\
\text { end } \\
\text { Ratios }\end{array}$ & $\begin{array}{c}\text { Post } \\
\text { Lever } \\
\text { age } \\
\text { Ratios }\end{array}$ & $\begin{array}{c}\text { Pre } \\
\text { Total }\end{array}$ & $\begin{array}{c}\text { Post } \\
\text { Total }\end{array}$ & $\begin{array}{c}\text { Pre } \\
\text { SVC }\end{array}$ & $\begin{array}{c}\text { Post } \\
\text { SVC }\end{array}$ & $\begin{array}{c}\text { Period } \\
\text { Differe } \\
\text { nce }\end{array}$ & $\begin{array}{c}\text { SVC } \\
\text { Differe } \\
\text { nce }\end{array}$ \\
\hline 1 & DB & 0.92 & 14.54 & 11.26 & 0.80 & 20.45 & 429.70 & 26.72 & 450.95 & 8.34 & 18.98 & 424.23 & 10.64 \\
\hline 2 & FBN & 1.13 & 14.98 & 12.16 & 0.94 & 20.50 & 28.34 & 28.27 & 49.77 & 45.34 & 65.50 & 21.51 & 20.16 \\
\hline 3 & UBN & 0.95 & 13.09 & 9.49 & 0.59 & 17.92 & 10.20 & 23.54 & 28.71 & 26.33 & 54.08 & 5.17 & 27.75 \\
\hline 4 & ABN & 0.73 & -4.89 & 15.06 & 0.75 & 20.48 & 88.16 & 10.90 & 109.40 & 4.13 & 18.35 & 98.50 & 14.22 \\
\hline 5 & WEMA & 1.05 & 11.63 & 28.57 & 0.32 & 8.82 & 2.21 & 41.24 & 11.36 & 7.67 & 14.17 & -29.88 & 6.50 \\
\hline 6 & ITCB & 1.01 & 12.72 & 7.81 & 0.67 & 13.90 & 15.58 & 21.54 & 30.16 & 10.84 & 31.49 & 8.62 & 20.65 \\
\hline 7 & AFBN & 1.08 & 22.08 & 21.04 & 0.72 & 43.44 & 5.08 & 44.20 & 49.24 & 16.07 & 25.79 & 5.05 & 9.72 \\
\hline 8 & FCMB & 0.89 & 23.07 & 4.71 & 0.76 & 21.71 & 5.47 & 28.67 & 27.95 & 5.41 & 17.44 & -0.72 & 12.03 \\
\hline 9 & OCBI & 1.33 & 0.00 & 10.24 & 2.88 & 34.75 & -23.53 & 11.57 & 14.10 & 13.04 & 27.64 & 2.53 & 14.60 \\
\hline
\end{tabular}

\section{CAPITAL RESTRUCTURING}

\begin{tabular}{|c|c|c|c|c|c|c|c|c|c|c|c|c|c|}
\hline ID & Bank & $\begin{array}{c}\text { Pre } \\
\text { Profita } \\
\text { bility } \\
\text { Ratios }\end{array}$ & $\begin{array}{c}\text { Pre } \\
\text { Divid } \\
\text { end } \\
\text { Ratios }\end{array}$ & $\begin{array}{c}\text { Pre } \\
\text { Lever } \\
\text { age } \\
\text { Ratios }\end{array}$ & $\begin{array}{c}\text { Post } \\
\text { Profit } \\
\text { ability } \\
\text { Ratios }\end{array}$ & $\begin{array}{c}\text { Post } \\
\text { Divide } \\
\text { end } \\
\text { Ratios }\end{array}$ & $\begin{array}{c}\text { Post } \\
\text { Lever } \\
\text { age } \\
\text { Ratios }\end{array}$ & $\begin{array}{c}\text { Pre } \\
\text { Total }\end{array}$ & $\begin{array}{c}\text { Post } \\
\text { Total }\end{array}$ & $\begin{array}{c}\text { Pre } \\
\text { SVC }\end{array}$ & $\begin{array}{c}\text { Post } \\
\text { SVC }\end{array}$ & $\begin{array}{c}\text { Period } \\
\text { Differe } \\
\text { nce }\end{array}$ & $\begin{array}{c}\text { SVC } \\
\text { Differe } \\
\text { nce }\end{array}$ \\
\hline 1 & GTB & 1.11 & 10.02 & 13.51 & 0.68 & 17.31 & 13.22 & 24.64 & 31.21 & 13.71 & 38.63 & 6.58 & 24.92 \\
\hline 2 & ZIB & 1.15 & 12.45 & 9.72 & 0.85 & 21.58 & 347.91 & 23.31 & 370.35 & 20.24 & 55.21 & 347.03 & 34.97 \\
\hline 3 & ECO & 0.63 & 22.46 & 4.89 & 0.78 & 94.33 & 219.56 & 27.98 & 314.67 & 4.80 & 24.15 & 286.70 & 19.35 \\
\hline
\end{tabular}

\section{COMBINED DATA}

\begin{tabular}{|c|c|c|c|c|c|c|c|c|c|c|c|c|c|}
\hline ID & Bank & $\begin{array}{c}\text { Pre } \\
\text { Profita } \\
\text { bility } \\
\text { Ratios }\end{array}$ & $\begin{array}{c}\text { Pre } \\
\text { Divid } \\
\text { end } \\
\text { Ratios }\end{array}$ & $\begin{array}{c}\text { Pre } \\
\text { Lever } \\
\text { age } \\
\text { Ratios }\end{array}$ & $\begin{array}{c}\text { Post } \\
\text { Profit } \\
\text { ability } \\
\text { Ratios }\end{array}$ & $\begin{array}{c}\text { Post } \\
\text { Divide } \\
\text { end } \\
\text { Ratios }\end{array}$ & $\begin{array}{c}\text { Post } \\
\text { Lever } \\
\text { age } \\
\text { Ratios }\end{array}$ & $\begin{array}{c}\text { Pre } \\
\text { Total }\end{array}$ & $\begin{array}{c}\text { Posta } \\
\text { Total }\end{array}$ & $\begin{array}{c}\text { Pre } \\
\text { SVC }\end{array}$ & $\begin{array}{c}\text { Post } \\
\text { SVC }\end{array}$ & $\begin{array}{c}\text { Period } \\
\text { Differe } \\
\text { nce }\end{array}$ & $\begin{array}{c}\text { SVC } \\
\text { Differe } \\
\text { nce }\end{array}$ \\
\hline 1 & FNB & 0.96 & 11.47 & 6.46 & 0.92 & 22.77 & 10.01 & 18.89 & 33.70 & 3.34 & 10.59 & 14.81 & 7.25 \\
\hline 2 & STLB & 0.81 & 29.99 & 6.08 & 0.52 & 35.37 & 9.64 & 36.88 & 45.53 & 7.48 & 8.47 & 8.65 & 0.99 \\
\hline 3 & ST-IB & 0.64 & 10.88 & 6.81 & 0.74 & 24.39 & 23.47 & 18.34 & 48.60 & 8.52 & 17.74 & 30.26 & 9.22 \\
\hline 4 & UBA & 1.22 & 12.66 & 18.28 & 0.90 & 21.35 & 1050.36 & 32.17 & 1072.62 & 14.07 & 49.04 & 1040.45 & 34.97 \\
\hline 5 & FDLT & 0.89 & 12.23 & 7.89 & 0.70 & 26.21 & 1.50 & 21.01 & 28.41 & 5.75 & 9.26 & 7.41 & 3.51 \\
\hline
\end{tabular}




\begin{tabular}{|c|c|c|c|c|c|c|c|c|c|c|c|c|c|}
\hline 6 & PHB & 0.17 & 1.27 & 1.76 & 0.57 & 15.22 & 5.67 & 3.20 & 21.47 & 0.00 & 22.33 & 18.26 & 22.33 \\
\hline 7 & SKYE & 0.77 & 13.98 & 18.21 & 0.80 & 21.84 & 23.74 & 32.97 & 46.39 & 3.68 & 12.43 & 13.42 & 8.76 \\
\hline 8 & SPRG & 1.09 & 20.19 & 7.28 & 0.22 & 7.91 & 1.18 & 28.56 & 9.30 & 3.64 & 6.87 & -19.25 & 3.23 \\
\hline 9 & UNITY & 0.00 & 0.00 & 0.00 & 0.01 & 45.80 & 16.22 & 0.00 & 62.04 & 0.00 & 5.46 & 62.04 & 5.46 \\
\hline 10 & DB & 0.92 & 14.54 & 11.26 & 0.80 & 20.45 & 429.70 & 26.72 & 450.95 & 8.34 & 18.98 & 424.23 & 10.64 \\
\hline 11 & FBN & 1.13 & 14.98 & 12.16 & 0.94 & 20.50 & 28.34 & 28.27 & 49.77 & 45.34 & 65.50 & 21.51 & 20.16 \\
\hline 12 & UBN & 0.95 & 13.09 & 9.49 & 0.59 & 17.92 & 10.20 & 23.54 & 28.71 & 26.33 & 54.08 & 5.17 & 27.75 \\
\hline 13 & ABN & 0.73 & -4.89 & 15.06 & 0.75 & 20.48 & 88.16 & 10.90 & 109.40 & 4.13 & 18.35 & 98.50 & 14.22 \\
\hline 14 & WEMA & 1.05 & 11.63 & 28.57 & 0.32 & 8.82 & 2.21 & 41.24 & 11.36 & 7.67 & 14.17 & -29.88 & 6.50 \\
\hline 15 & ITCB & 1.01 & 12.72 & 7.81 & 0.67 & 13.90 & 15.58 & 21.54 & 30.16 & 10.84 & 31.49 & 8.62 & 20.65 \\
\hline 16 & AFBN & 1.08 & 22.08 & 21.04 & 0.72 & 43.44 & 5.08 & 44.20 & 49.24 & 16.07 & 25.79 & 5.05 & 9.72 \\
\hline 17 & FCMB & 0.89 & 23.07 & 4.71 & 0.76 & 21.71 & 5.47 & 28.67 & 27.95 & 5.41 & 17.44 & -0.72 & 12.03 \\
\hline 18 & OCBI & 1.33 & 0.00 & 10.24 & 2.88 & 34.75 & -23.53 & 11.57 & 14.10 & 13.04 & 27.64 & 2.53 & 14.60 \\
\hline 19 & GTB & 1.11 & 10.02 & 13.51 & 0.68 & 17.31 & 13.22 & 24.64 & 31.21 & 13.71 & 38.63 & 6.58 & 24.92 \\
\hline 20 & ZIB & 1.15 & 12.45 & 9.72 & 0.85 & 21.58 & 347.91 & 23.31 & 370.35 & 20.24 & 55.21 & 347.03 & 34.97 \\
\hline 21 & ECO & 0.63 & 22.46 & 4.89 & 0.78 & 94.33 & 219.56 & 27.98 & 314.67 & 4.80 & 24.15 & 286.70 & 19.35 \\
\hline
\end{tabular}

